\title{
Carbon Dioxide Emissions from the Tropical Dowleiswaram Reservoir on the Godavari River, Southeast of India
}

\author{
M. H. K. Prasad, V. V. S. S. Sarma*, V. V. Sarma, M. S. Krishna, N. P. C. Reddy \\ National Institute of Oceanography, Council of Scientific and Industrial Research (CSIR), \\ Regional Centre, Visakhapatnam, India \\ Email: ${ }^{*}$ sarmav@nio.org
}

Received January 9, 2013; revised February 19, 2013; accepted March 15, 2013

Copyright (C) 2013 M. H. K. Prasad et al. This is an open access article distributed under the Creative Commons Attribution License, which permits unrestricted use, distribution, and reproduction in any medium, provided the original work is properly cited.

\begin{abstract}
Time-series observations were conducted in the Dowleiswaram dam reservoir that was constructed on the largest monsoonal river in India to understand the source of inorganic carbon, and fluxes to the atmosphere. The reservoir stores water during dry period of six months and water increases during the period when Indian subcontinent receives significant rainfall. Significant modification of organic matter was noticed during storage period indicated by decrease in $\mathrm{pH}$ from 7.5 to 6.4 and oxygen saturation from $\sim 95 \%$ to $65 \%$. The relationship of dissolved inorganic carbon (DIC) with oxygen saturation, dissolved organic carbon (DOC) and isotopic ratios of DIC suggests that heterotrophic activities are the major source of inorganic carbon to the reservoir. In addition to this, ground water exchange also contributes significantly to the inorganic carbon pool in the reservoir. Nutrients released due to decomposition of organic matter in the reservoir supports both autotrophic and heterotrophic activities. The $\mathrm{pCO}_{2}$ levels in the reservoir varied between 3944 and 16,042 $\mu \mathrm{atm}$ and higher $\mathrm{pCO}_{2}$ levels were noticed during peak discharge period. The annual mean $\mathrm{CO}_{2}$ fluxes from the reservoir amounted to $112 \pm 126 \mathrm{mmolC} \mathrm{m}{ }^{-2} \cdot \mathrm{d}^{-1}$ and $\sim 6$ times higher fluxes were noticed during discharge period compared to dry period and such high fluxes during discharge period were contributed by both high $\mathrm{pCO}_{2}$ levels and winds. It was further noticed that dam reservoir is a strong source of $\mathrm{pCO}_{2}$ to the estuary wherein $<1000 \mu$ atm of $\mathrm{pCO}_{2}$ during dry period and $>15,000 \mu \mathrm{atm}$ during discharge period were observed. Our study also indicates that Dowleiswaram dam reservoir is a strong source of $\mathrm{CO}_{2}$ to atmosphere, even though it is much smaller than Brazilian (tropical) reservoir but higher than European reservoirs.
\end{abstract}

Keywords: Inorganic Carbon System; $\mathrm{CO}_{2}$ Flux; Heterotrophic Activity; Ground Water Exchange; Reservoir

\section{Introduction}

The global emissions of the $\mathrm{CO}_{2}$ to the atmosphere from the inland waters are similar in magnitude to the uptake by the ocean; on the other hand, the organic carbon burial in the sediments of inland waters far exceeds the same on the ocean floor $[1,2]$. Reservoirs are known to be strong source of greenhouse gases to the atmosphere [3-6]. The fluxes of greenhouse gases in the reservoirs in the northern hemisphere were usually $3-10$ times higher than those in natural lakes at their maximum [2]. Normally a majority of the freshwater ecosystems are supersaturated in $\mathrm{CO}_{2}$, and hence act as a strong source of $\mathrm{CO}_{2}$ to the atmosphere [7]. Particularly these emissions are more in the tropical regions due to flooding of carbon from the

"Corresponding author. forest and high temperatures lead to high fluxes of greenhouse gases to the atmosphere [8]. Several processes are responsible for $\mathrm{CO}_{2}$ emissions from the reservoirs such as bacterial respiration, photo-oxidation [9], surface and ground water inflow of aqueous $\mathrm{CO}_{2}[10]$ and $\mathrm{CO}_{2}$ production in sediments $[11,12]$. Nevertheless, the excess $\mathrm{CO}_{2}$ is often attributed to the heterotrophic respiration of allochthonous organic matter $[13,14]$. However, the relation between aquatic metabolism and $\mathrm{CO}_{2}$ emission need to be explicitly tested as there are several processes responsible for this relationship.

The reservoirs receive significant amount of organic and inorganic material from the upstream river [15-17] and it is modified over a period during storage. Such process is rather controlled by several physico-chemical parameters such as water column temperature, nutrients 
load, microbial abundance, quality of organic matter etc. The water quality of the reservoir with reference to organic load is generally depending on the usage of water and settlements around the river basin $[18,19]$. Numerous studies on water quality assessment and tropic state index were conducted in different reservoir systems [20-24]. Eutrophication in these reservoirs is mostly due to overloading of nutrients from external sources derived from insufficiently treated sewage effluents and agricultural runoff [25-27]. Several factors such as size of the catchment basin, anthropogenic land use, morphometric features, age of reservoir, water residence time and trophic state make the reservoirs different from one other.

Several studies [28-31] had been carried out on some reservoirs in India and all studies were mainly concentrated on identifying nutrient sources to the reservoir causing eutrophication. No studies have been carried out so far on emissions of trace gases such as $\mathrm{CO}_{2}$, from the reservoirs in India. India houses more than 376 reservoirs (http://en.wikipedia.org/wiki/List_of_dams_and_reservoirs in_India) which were constructed on major rivers mainly to meet agricultural, electric power, industrial and domestic needs. High nutrient concentrated in the Godavari estuary during peak discharge period and was attributed that dam reservoir is a significant source of nutrients to estuary [32]. They [32] noticed high ammonium (36.1 \pm $22 \mu \mathrm{M})$ concentrations in the estuary during peak discharge period which was much higher compared to the dry period $(5.3 \pm 1 \mu \mathrm{M})$. The fertilizers use along the east coast of India is high $\left(49.3 \mathrm{~kg} \cdot\right.$ hectare $\left.^{-1}\right)$ that amounts almost double to the country's average (Department of Agriculture, http://www.indiastat.com/agriculture/2/stats. aspx). Availability of nutrients promotes photosynthesis, although subject to the availability of light, enhancing the organic material loading into water. The observed high bacterial respiration in the Godavari $(20.6 \pm 7.2 \mu \mathrm{mol}$ $\mathrm{C} \cdot \mathrm{1}^{-1} \cdot \mathrm{d}^{-1}$ ) during discharge period [33] was supported by the allochthonous organic matter [34]. They [33] further noticed record levels of $\mathrm{pCO}_{2}(30,000 \mu \mathrm{atm})$ during peak discharge period from the Godavari estuary, which was influenced by discharge from the Dowleiswaram dam reservoir [33]. Such high emissions were related to modification of organic matter in the dam reservoir and resuspension of sediments (mainly porewater). More recently $\mathrm{CO}_{2}$ emissions from the Indian estuaries [35] were also an order of magnitude higher during peak discharge period, when they receive water from dam reservoir, than dry period and attributed that dams modify carbon system during its storage in the reservoir. The enriched nutrients and warmer water temperatures (mostly $30^{\circ} \mathrm{C}$ ), being situated in tropical belt, during dry period supports microbial modification of organic matter in the reservoir. The objective of this study is to examine the variations in inorganic carbon system in the Dowleiswaram dam res- ervoir, which was constructed on the largest monsoonal river in India, Godavari river, and processes responsible for oversaturation of $\mathrm{CO}_{2}$ using 24 months time-series observations.

\section{Study Area}

Godavari is one of the largest monsoonal rivers in India with a basin of $3.1 \times 10^{5} \mathrm{~km}^{2}$ with 25 tributaries and an annual discharge to the estuary was recently estimated to be $70 \mathrm{~km}^{3}$ [36]. The river originates at about $1600 \mathrm{~m}$ above the mean sea level near Nasik in the Western Ghats and traverses about $1480 \mathrm{~km}$ before draining into the Bay of Bengal (Figure 1, Table 1). Godavari river is dammed at several locations along its course for irrigation and domestic consumption of freshwater. A big dam built just after source of the river at Trimbakeshwar is in the town of Gangapur, which provides drinking water to the residents of Nasik and to thermal power station situated downstream at Eklahare. The Jayakwadi dam near Paithan is the largest eastern dam, which was built to address the problem of drought in Marathwada region of Maharashtra state. A multipurpose project on the Godavari viz., Nizam Sagar reservoir and Sriram Sagar reservoirs serves the purpose of irrigation and power in four districts of Northern Telengana regions of Andhra Pra-

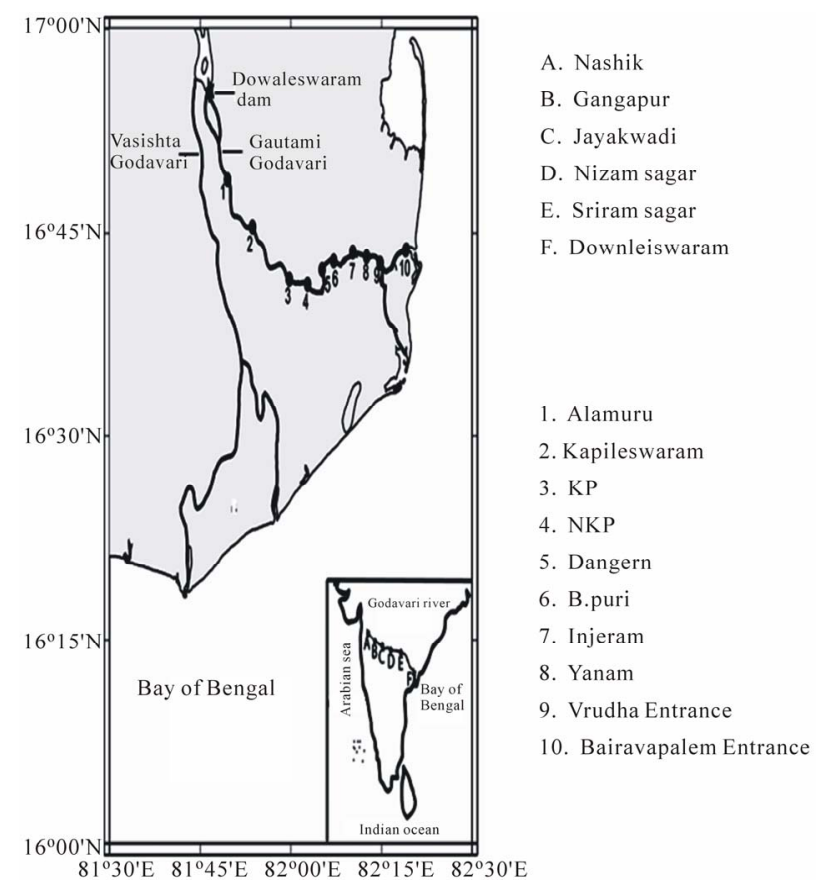

Figure 1. Map showing the study area and locations of monthly time-series observations at Dowleiswaram dam Reservoir station (*) and Goutami Godavari stations (upstream \& downstream of Estuary) where samples collected during dry \& wet seasons (1 - 10). Inset shows source point (A) and dams (B-F) over Godavari River along Indian sub continent. 
Table 1. Characteristics of the Dowleiswaram dam reservoir.

\begin{tabular}{cc}
\hline Characteristics & Reservoir \\
\hline Country & India \\
State & Andhra Pradesh \\
Latitude & $16^{\circ} 15^{\prime} \mathrm{N}$ \\
Longitude & $82^{\circ} 15^{\prime} \mathrm{E}$ \\
Average air temperature $\left({ }^{\circ} \mathrm{C}\right)$ & 30 \\
Annual precipitation $(\mathrm{mm})$ & 1512 \\
Date of impoundment & 1987 \\
Watershed & Nasik \\
Watershed area $\left(\mathrm{km}^{2}\right)$ & $3.1 \times 10^{5}$ \\
Water discharge $\left(\mathrm{m}^{3} \cdot \mathrm{s}^{-1}\right)$ & 70 \\
Reservoir surface $\left(\mathrm{km}^{2}\right)$ & 70 \\
Volume $\left(\mathrm{km}^{3}\right)$ & 350 \\
Residence time $\left(\mathrm{month}^{2}\right)$ & $5-6$ \\
Mean depth $(\mathrm{m})$ & $3-5$ \\
\hline
\end{tabular}

desh. Dowaleiswaram barrage is an irrigation structure, built on last stretch of Godavari river before it empties into Bay of Bengal. This dam originally constructed in 1850 and rebuilt in 1987 at a distance of eight kilometers from the downstream of Rajahmundry. After the dam, the river is divided into two streams (Figure 1), viz., the Gautami and Vasista, forms the dividing line between West and East Godavari districts of Andhra Pradesh. This dam is approximately $60 \mathrm{~km}$ upstream from the mouth of the river. The sampling station is fixed at the barrage (Figure 1) and the water samples were collected on monthly intervals from January 2010 to December 2011 for a period of two years. In addition to this, samples were also collected in the Gautami Godavari estuary (Figure 1), which is the major estuary with $>70 \%$ of flow, at 10 stations after dam and up to mouth of the estuary during peak discharge (August) and dry period (April) to examine the impact of discharge on the estuary.

\section{Material and Methods}

Temperature, Salinity and Depth were measured using a portable Conductivity-Temperature-Depth profiler (CTD; SBE-19 plus, Sea-Bird Electronics, USA). Surface and bottom water samples were collected using a 5 L Niskin bottle for Dissolved Oxygen (DO), pH, DIC, Chlorophyll-a (Chl a) and Nutrients. DO was measured by Winkler titration method [37] using automated potentiometric detection (835 Titranado, Metrohm, Switzerland). Nutrients analyses were carried on filtered water samples following the standard spectrophotometric procedures [38]. The precisions of nitrate+nitrite $\left(\mathrm{NO}_{3}+\mathrm{NO}_{2}\right)$, ammonium, phosphate and silicate were $\pm 0.2, \pm 0.2, \pm 0.1$ and $\pm 0.2 \mu \mathrm{M}$, respectively. About 150 to $500 \mathrm{ml}$ of the water sample was filtered through glass fiber filter (GF/F; 0.7 $\mu \mathrm{m}$; Whatman) and Chl-a retained on the filter was extracted with $N, N$-dimethyl formamide at $4^{\circ} \mathrm{C}$ in dark for $24 \mathrm{~h}$ and fluorescence was measured using spectrofluorometer (Varian Instruments, UK) as per the procedure [39]. The analytical precision for Chl-a analysis was $\pm 4 \%$. The $\mathrm{pH}$ was measured by potentiometric (835 Titranado, Metrohm, Switzerland) standard operating Procedures (SOP) [40]. Dissolved inorganic carbon (DIC) was measured using Coulometer (UIC Inc., USA) using automated subsampling system developed in house. The precision for $\mathrm{pH}$, and DIC were \pm 0.002 , and $1.8 \mu \mathrm{mol} \cdot \mathrm{l}^{-1}$ respectively. The accuracy of the DIC measurement was tested using Certified Reference Material supplied by Dr. A. G. Dickson, Scripps Institute of Oceanography, USA and internal standards and found to be within $1.5 \%$. The $\mathrm{pCO}_{2}$ was computed using measured salinity, temperature, nutrients (phosphate and silicate), $\mathrm{pH}$ and DIC utilising dissociation constants given by [41]. Dissolved organic carbon (DOC) was analysed by total organic carbon analyser (TOC; Shimadzu, Japan) following high temperature catalytic oxidation method. The water samples were incubated in the dark bottle, which was wrapped with black tape and aluminium foil and changes in DO over 24-hour was measured following the same given above. Changes in DO in the dark bottles, from that of initial, were used to quantify community respiration. All these analyses were completed within $12 \mathrm{~h}$ of sampling at the shore-based laboratory established on the bank of the river. $\delta^{13} \mathrm{C}_{\mathrm{DIC}}$ was measured using Mass Spectrometer (Delta V Plus, Thermo Scientific, Germany) attached to Gas Bench (Finnigan, Gas Bench II, Thermo Scientific, Germany) using acidification technique with the precision of $0.2 \%$. Discharge data were obtained from the Dam authorities at Dowaleiswaram.

\section{Results and Discussion}

\subsection{Variations in Discharge, Nutrients, Dissolved Oxygen and Phytoplankton Biomass in the Dam Reservoir}

The dam reservoir receives freshwater from the upstream river only during monsoon period when Indian subcontinent receives significant rain fall. The rain fall during the study period varied between 6 and $504 \mathrm{~mm}$ with maximum during July-August (Figure 2(a)). The mean annual rainfall was less than half during $2011(78.8 \mathrm{~mm})$ compared to that of $2010(182.5 \mathrm{~mm})$. The monthly mean discharge ranged from 0 to $5839 \mathrm{~m}^{3} \cdot \mathrm{s}^{-1}$ with maximum during August (Figure 2(b)). The annual mean freshwa- 

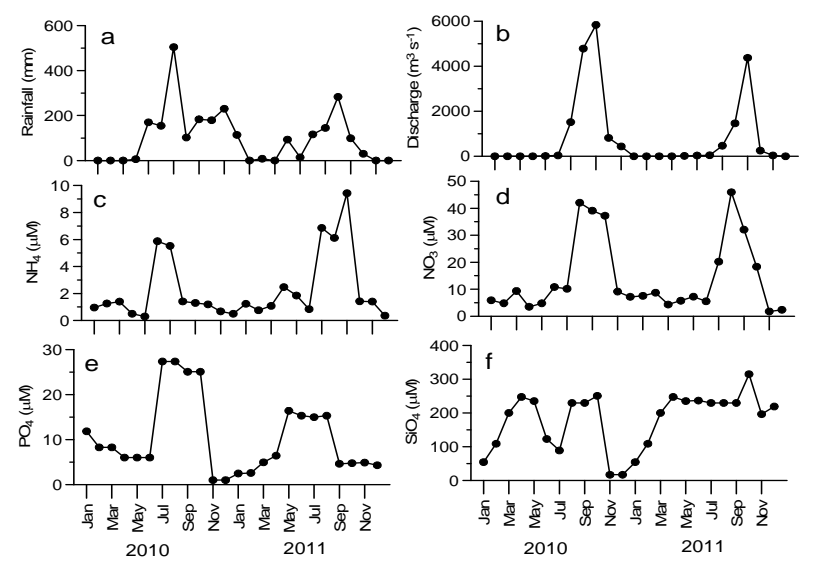

Figure 2. Time-series variations at reservoir in (a) rainfall $(\mathrm{mm})$; (b) river discharge $\left(\mathrm{m}^{3} / \mathrm{s}\right)$; (c) ammonium ( $\left.\mu \mathrm{M}\right)$; (d) nitrate $(\mu \mathrm{M})$; (e) phosphate $(\mu \mathrm{M})$; and (f) silicate $(\mu \mathrm{M})$.

ter discharge from the reservoir was 1921 and $836 \mathrm{~m}^{3} \cdot \mathrm{s}^{-1}$ respectively during 2010 and 2011 and it was consistent with the rainfall. The freshwater discharge into the estuary occurs from June to December with high during June to September (peak discharge period) and moderate from October to December (moderate discharge period). The discharge is controlled by dam authorities through lifting the dam gates when the discharge to the reservoir exceeds its capacity. From January to May, no discharge occurs (called dry period) from the dam reservoir and the water is stored until the monsoon. However, this ideal state gets altered depending on the variability of southwest monsoon rainfall.

Nutrient concentrations showed significant intra-annual variations with higher concentrations during discharge than dry period. For instance, ammonium concentrations ranged between 0.4 and $12.6 \mu \mathrm{M}$ with mean ammonium concentration were consistently high (4.31 \pm $4.22 \mu \mathrm{M})$ in both years during peak discharge compared to dry and moderate discharge periods. Nitrate and Phosphate varied between 1.8 to $45.9 \mu \mathrm{M}$ and 0.5 to $27.4 \mu \mathrm{M}$ with highest values noticed in peak discharge period (21.01 \pm 18.21 of nitrate and phosphate of $12.6 \pm 12.8$ $\mu \mathrm{M})$ than dry and moderate discharge period respectively (Figures 2(c)-(e)). High nutrient concentrations (both nitrate and phosphate) were due to both in situ decomposition of organic matter and impact of agricultural runoff into the reservoir. Application of fertilizers such as urea, di-ammonium phosphate and potash is quite high $\sim 24$ $34 \mathrm{~kg}$ hectare ${ }^{-1}$ along the Indian rivers (Indian agricultural department). Excess fertilizers finally washed into different water bodies including the reservoirs, as reported in Oyun Reservoir, Nigeria [21]. Thus high concentrations of nutrients enhance the organic load that promotes both bacterial and primary producers. Relatively high phosphate concentrations appeared in moderate discharge and dry period (Figure 2(e)) in the study region may be impact of anthropogenic inputs through leaching and run-off of nitro-phosphate fertilizers from nearby farmlands around the reservoir [33]. The impact of washing of cow dungs and washing with phosphate based detergents and soaps into the reservoir are also significant sources to the reservoir [21].

High silicate concentrations during observational period (Figure 2(f)) may be due to weathering/leaching of diverse siliclastic and carbaceous matrices [42] and washing of alumnio-silicate minerals present in the rocky substrate basement complex aided by dilution from the rains [21]. However, silicate concentrations varied from 16.8 to $314.7 \mu \mathrm{M}$ with the highest value of $243.3 \pm 62.87$ $\mu \mathrm{M}$ during moderate discharge period. These enhanced nutrient concentrations and shallowness may lead to eutrophication in the reservoir system coincided with the earlier reports $[43,44]$. The phytoplankton biomass (represented as Chl-a) varied from 1.3 to $38 \mathrm{mg} \cdot \mathrm{m}^{-3}$ and relatively higher biomass was found during moderate discharge period (Figure 3(a)). Highest primary production rates during the moderate discharge period in Godavari estuarine system were observed [34] as well and were attributed to low suspended load and high stratification. Earlier reports [36,45] also revealed that stability and clarity of water column are two most important factors for the development and intensification of phytoplankton blooms in the estuary.

The reservoir was mostly undersaturated during entire study period and varied between $70 \%$ and 104\% (Figure 3(b), Table 2). The DO levels decreased from $94.8 \%$ (January) to $70 \%$ (May) during storage period suggesting dominant heterotrophic activity. The DOC also decreased from 473 to $312 \mu \mathrm{M}$ (Figure 3(c)) during storage period further confirming that significant heterotrophic respiration during storage period resulting in decrease in DOC and DO levels in the reservoir. High heterotrophic (community) respiration was observed $\left(210\right.$ - $245 \mathrm{mmol} \mathrm{O}_{2}$ $\mathrm{m}^{-2} \cdot \mathrm{d}^{-1}$; Figure 3(d)) during dry period than peak discharge period $\left(65-173 \mathrm{mmol} \mathrm{O}_{2} \mathrm{~m}^{-2} \cdot \mathrm{d}^{-1}\right.$; Figure $3(\mathbf{d})$ )
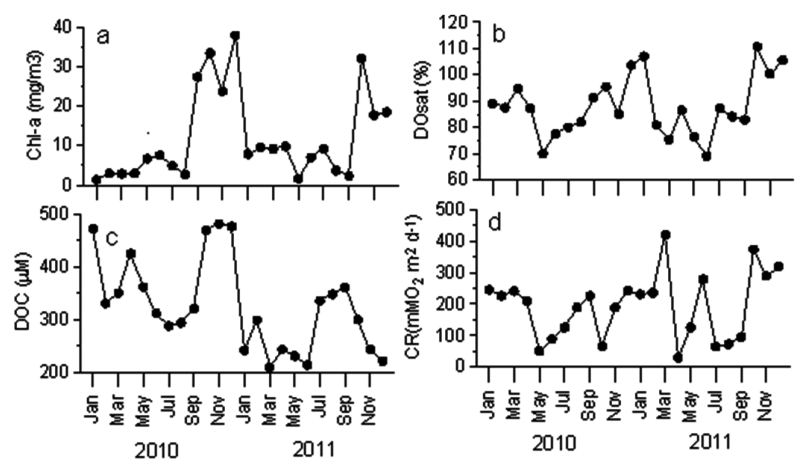

Figure 3. Time-series variations at reservoir in (a) Chlorophyll-a; (b) DO saturation; (c) DOC; and (d) community respiration (CR). 
Table 2. Variations in temperature, $\mathrm{Chl}-\mathrm{a}, \mathrm{DO}_{\text {sat }}(\%), \mathrm{pH}, \mathrm{DIC}, \mathrm{pCO}_{2}$ and $\mathrm{CO}_{2}$ flux in the dam reservoir.

\begin{tabular}{|c|c|c|c|c|c|c|c|}
\hline Month & Temperature $\left({ }^{\circ} \mathrm{C}\right)$ & $\begin{array}{c}\text { Chl-a } \\
\left(\mathrm{mg} \cdot \mathrm{m}^{-3}\right)\end{array}$ & $\mathrm{DO}_{\text {sat }}(\%)$ & $\mathrm{pH}$ & $\mathrm{DIC}(\mu \mathrm{M})$ & $\mathrm{pCO}_{2}(\mu \mathrm{atm})$ & $\begin{array}{c}\mathrm{CO}_{2} \mathrm{flux}^{-2} \\
\left(\mathrm{mmolC} \mathrm{m}^{-2} \cdot \mathrm{d}^{-1}\right) \\
\end{array}$ \\
\hline Jan 2010 & 26.74 & 1.35 & 89.2 & 7.250 & 1771 & 5739 & 24.4 \\
\hline Feb 2010 & 30.21 & 2.97 & 87.6 & 7.228 & 2142 & 7667 & 36.1 \\
\hline Mar 2010 & 31.45 & 2.88 & 94.8 & 7.151 & 1230 & 5256 & 15.4 \\
\hline Apr 2010 & 32.74 & 3.00 & 87.2 & 7.095 & 840 & 4096 & 24.4 \\
\hline May 2010 & 33.39 & 6.71 & 70.0 & 6.965 & 620 & 3944 & 60.6 \\
\hline Jun 2010 & 30.72 & 7.55 & 77.8 & 6.708 & 973 & 9352 & 255.5 \\
\hline Jul 2010 & 29.26 & 4.91 & 80.1 & 6.759 & 1004 & 8630 & 211.3 \\
\hline Aug 2010 & 30.40 & 2.74 & 82.1 & 6.735 & 911 & 8318 & 218.3 \\
\hline Sep 2010 & 31.19 & 27.41 & 91.2 & 6.735 & 1000 & 9258 & 108.9 \\
\hline Oct 2010 & 30.81 & 33.45 & 95.4 & 7.270 & 1537 & 5091 & 21.0 \\
\hline Nov 2010 & 29.15 & 23.83 & 85.2 & 7.450 & 1841 & 4059 & 44.0 \\
\hline Dec 2010 & 26.69 & 37.97 & 103.7 & 7.354 & 1985 & 5168 & 9.7 \\
\hline Jan 2011 & 28.12 & 7.90 & 107.1 & 7.250 & 2013 & 6524 & 18.7 \\
\hline Feb 2011 & 29.92 & 9.50 & 80.9 & 7.228 & 1568 & 5612 & 14.6 \\
\hline Mar 2011 & 30.42 & 9.20 & 75.4 & 7.025 & 1636 & 8979 & 31.5 \\
\hline Apr 2011 & 31.62 & 9.81 & 86.6 & 6.844 & 1110 & 8724 & 91.7 \\
\hline May 2011 & 32.55 & 1.65 & 76.4 & 7.063 & 1248 & 6560 & 100.9 \\
\hline Jun 2011 & 32.75 & 7.04 & 69.0 & 6.506 & 1211 & 15880 & 472.8 \\
\hline Jul 2011 & 30.55 & 9.19 & 87.3 & 6.651 & 1211 & 12435 & 422.4 \\
\hline Aug 2011 & 31.05 & 3.69 & 84.2 & 6.476 & 889 & 12083 & 198.2 \\
\hline Sep 2011 & 32.35 & 2.31 & 83 & 6.703 & 1642 & 16042 & 125.1 \\
\hline Oct 2011 & 31.31 & 32.20 & 110.6 & 6.914 & 1783 & 11944 & 17.6 \\
\hline Nov 2011 & 30.22 & 17.73 & 100.4 & 6.914 & 2169 & 14132 & 92.2 \\
\hline Dec 2011 & 27.79 & 18.52 & 105.6 & 6.889 & 2343 & 15335 & 72.4 \\
\hline
\end{tabular}

further suggesting that dominant heterotrophy in the dam reservoir. High nutrients concentration during dry period, due to in situ decomposition of organic matter and washed out agricultural fertilizers, and high temperatures $\left(\sim 30^{\circ} \mathrm{C}\right)$ promoted high respiration rates in the reservoir during dry period.

\subsection{Variations in Inorganic Carbon System in the Dam Reservoir}

The $\mathrm{pH}$ in the dam reservoir ranged from 6.47 to 7.45 with lower values found between June and August (Figure 4(a), Table 2). The $\mathrm{pH}$ values decreased gradually from January (7.25) to May (6.50) suggesting that significant modification of inorganic carbon system during storage period. The DIC concentrations were decreased from 1771 to $620 \mu \mathrm{M}$ (Figure 4(b)) from January to May while Chl-a increased from 1.35 to $6.71 \mathrm{mg} \cdot \mathrm{m}^{-3}$ (Figure 3(a)) during same period. Despite high heterotrophic
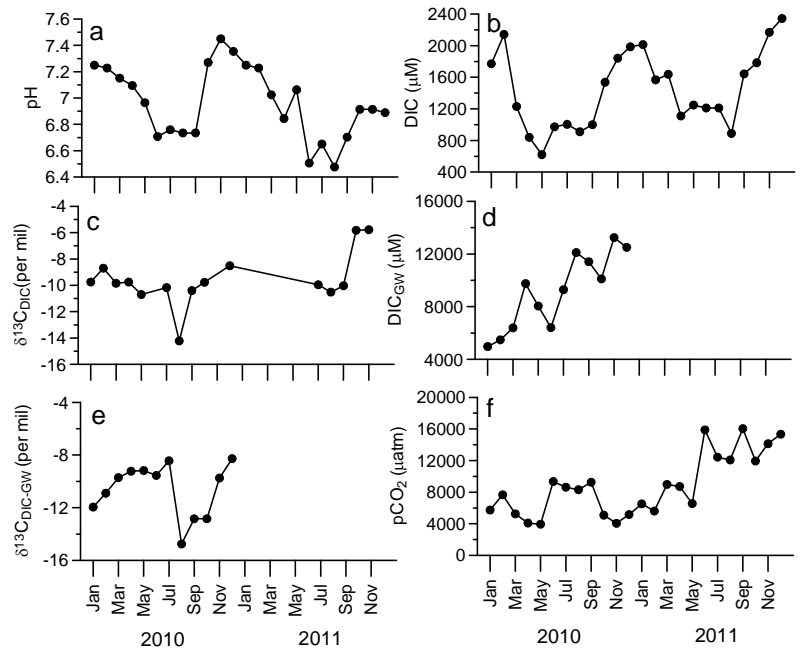

Figure 4. Time-series variations in (a) pH; (b) DIC of reservoir; (c) $\delta^{13} C_{D I C}$ of reservoir; (d) DIC of ground water; (e) $\delta^{13} \mathrm{C}_{\mathrm{DIC}}$ of ground water; and (f) $\mathrm{pCO}_{2}$ of reservoir. 
respiration during dry period, decrease in DIC could possibly resulted from efflux of $\mathrm{CO}_{2}$ to the atmosphere. The DIC showed significant negative correlation with DOC $\left(\mathrm{r}^{2}=0.36 ; \mathrm{p}<0.05\right.$; Figure 5(a)) and positive relation with community respiration $\left(\mathrm{r}^{2}=0.38 ; \mathrm{p}<0.05\right.$; Figure 5(b)) suggesting that microbial decomposition of organic matter is the strong source of DIC in the reservoir.

The low $\mathrm{pH}$ and DIC were also noticed during peak discharge period (June to August) and then increased towards December during moderate discharge period. The lowest phytoplankton biomass $\left(2.3\right.$ to $3.9 \mathrm{mg} \cdot \mathrm{m}^{-3}$; Figure 3(a)) was noticed during peak discharge period with high amount of suspended load (730 - $840 \mathrm{mg} \cdot \mathrm{l}^{-1}$ ) than dry period (12 - $82 \mathrm{mg} \cdot \mathrm{l}^{-1}$; our unpublished data) suggesting that less light penetration hindered phytoplankton growth [34]. In contrast, the increase in $\mathrm{pH}$ from 6.73 to 7.34 during moderate discharge period was in association with high phytoplankton biomass of 23.8 to $33.5 \mathrm{mg} \cdot \mathrm{m}^{-3}$ (Figure 3(a)) and increase in oxygen levels to oversaturation (Figure 3(b)) indicating that enhanced phytoplankton production led to increase in $\mathrm{pH}$ and DIC concentrations. The low $\mathrm{pH}$ values during peak discharge period (June-September) in the dam reservoir were also associated with high nutrients (Figures 3(c)-(f)) and organic matter load (Figure 3(c)) suggesting significant organic matter decomposition in their enroute to reservoir lead to decrease in $\mathrm{pH}$.

In order to examine the source of inorganic carbon in the dam reservoir, the isotopic composition of $\delta^{13} \mathrm{C}$ of DIC was measured during 2010. The $\delta^{13} \mathrm{C}_{\text {DIC }}$ varied between -14.2 and $-6.8 \%$ o and relatively lighter isotopic
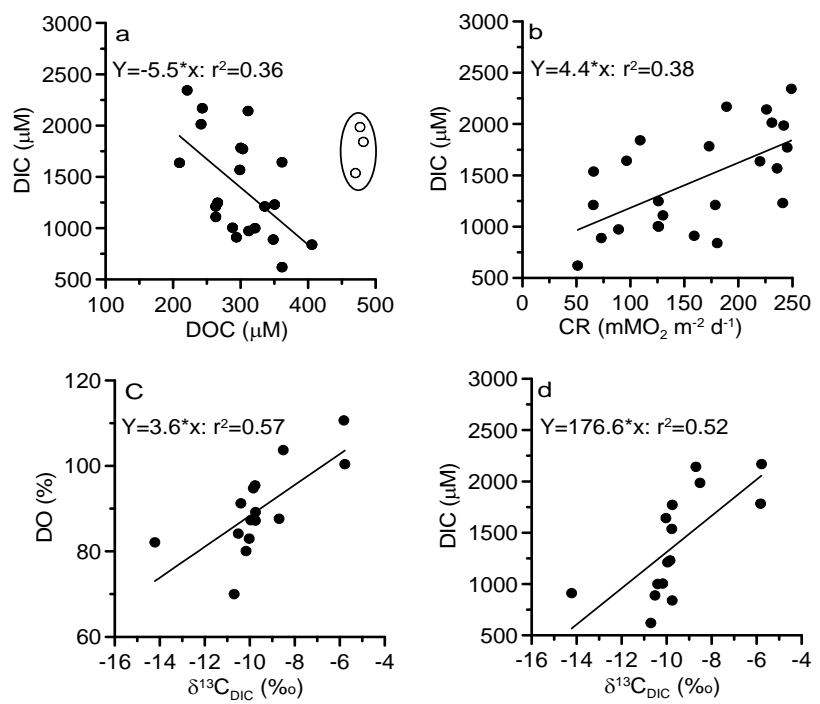

Figure 5. Relationship of dissolved inorganic carbon with (a) dissolved organic carbon; (b) heterotrophic community respiration (CR), and relationship of isotopic ratio of dissolved inorganic carbon; with (c) dissolved oxygen saturation; and (d) dissolved inorganic carbon. The point circles in the (a) were not used in construction of regression equation. values were noticed during peak discharge period $(-11.4$ $\pm 0.1 \%$ ) whereas heavier values were noticed during moderate discharge period $(-9.1 \%$ o $\pm 0.3 \%$ ) when high phytoplankton biomass of $>20 \mathrm{mg} \cdot \mathrm{m}^{-3}$ was noticed (Figure 4(c)). The isotopic ratios were more or less constant and greater during dry period $(-9.7 \% \mathrm{0} \pm 0.5 \% \mathrm{)})$ compared to peak discharge period. The $\delta^{13} \mathrm{C}_{\text {DIC }}$ showed strong positive relation with DO saturation $\left(\mathrm{r}^{2}=0.57\right.$; $\mathrm{p}<0.001$; Figure 5(c)) suggesting that heavier isotopic composition was driven by dominant autotrophy and vice versa for heterotrophy. Similarly DIC also showed positive relation with $\delta^{13} \mathrm{C}_{\text {DIC }}\left(\mathrm{r}^{2}=0.52 ; \mathrm{p}<0.001\right.$; Figure $\left.5(\mathbf{d})\right)$ further suggests that heterotrophy respiration is the major contributor for DIC during dry and peak discharge period whereas autotrophy contributed during moderate discharge period in the dam reservoir. The DIC concentrations in the ground waters were ranged between 4973 and $13246 \mu \mathrm{M}$ (Figure 4(d)) during study period with the isotopic ratio varied between $-14.7 \%$ and $-8.5 \%$ (Figure 4(e)). Interestingly the strong positive correlation of DIC and its isotopic ratios between ground and reservoir waters strongly suggest that significant contribution from the ground water is possible $\left(\mathrm{r}^{2}=0.61 ; \mathrm{p}<0.001\right.$; and $\mathrm{r}^{2}$ $=0.53 ; \mathrm{p}<0.001$ respectively). Recently it is reported [46] that the contribution of nutrients through exchange rates between ground water and reservoir is up to $30 \%$ $40 \%$ using Radium isotopes. Hence ground water exchange also contributed significant amount of inorganic carbon to the reservoir.

\subsection{Variations in $\mathrm{pCO}_{2}$ Levels and Its Fluxes at the Air-Water Interface}

The $\mathrm{pCO}_{2}$ levels in the dam reservoir ranged between 3944 and 16,042 $\mu$ atm with low during dry period and high in discharge period (Figure 4(f), Table 2). The mean $\mathrm{pCO}_{2}$ values during discharge period was almost double $(10,552 \pm 4065 \mu \mathrm{atm})$ to that of dry period (6310 $\pm 1742 \mu \mathrm{atm})$. Sharp increase in $\mathrm{pCO}_{2}$ was associated with initial discharge (June) while sharp decrease in $\mathrm{pCO}_{2}$ was associated with decrease in discharge (September). On the other hand, the $\mathrm{pCO}_{2}$ levels during peak discharge (July-August) were almost close to that of dry period (in case of 2010) while it was slightly higher during 2011. Significant inter-annual variations in $\mathrm{pCO}_{2}$ levels were observed in the dam reservoir. The $\mathrm{pCO}_{2}$ values during dry period of $2010(6009 \pm 2120 \mu \mathrm{atm})$ were not statistically different from that of 2011 (7279 \pm $1487 \mu \mathrm{atm})$ keeping variability into consideration whereas $\mathrm{pCO}_{2}$ levels during discharge period of 2010 (6721 \pm $2226 \mu \mathrm{atm})$ were two times less than that of $2011(13,980$ $\pm 1819 \mu \mathrm{atm})$. The significant difference in the $\mathrm{pCO}_{2}$ levels during discharge period was consistent with the higher annual mean discharge during $2010\left(1222 \mathrm{~m}^{3} \cdot \mathrm{s}^{-1}\right)$ than $2011\left(557 \mathrm{~m}^{3} \cdot \mathrm{s}^{-1}\right)$ and also consistent with the an- 
nual mean rainfall higher during $2010(137 \mathrm{~mm})$ than $2011(65 \mathrm{~mm})$. This suggests that weak monsoon during 2011 lead to low discharge enhancing water residence time in the reservoir for longer time resulting in modification of more organic matter. The mean DOC concentrations during 2010 were higher $(395 \pm 86 \mu \mathrm{M})$ than $2011(258 \pm 48 \mu \mathrm{M})$ further indicating that decomposition of more organic matter in the latter period led to high $\mathrm{pCO}_{2}$ levels. Significant differences in $\mathrm{pCO}_{2}$ levels were also found during moderate discharge period (October-December) with significantly lower $\mathrm{pCO}_{2}$ values during $2010(4772 \pm 619 \mu \mathrm{atm})$ than $2011(13803 \pm 1719$ $\mu \mathrm{atm})$ which was associated with high phytoplankton biomass during former $\left(31.7 \pm 7 \mathrm{mg} \cdot \mathrm{m}^{-3}\right)$ than 2011 year $\left(22.8 \pm 8 \mathrm{mg} \cdot \mathrm{m}^{-3}\right)$. This suggested that high phytoplankton biomass, thus high primary production, during moderate discharge period during 2011 led to low $\mathrm{pCO}_{2}$ levels. The $\mathrm{pCO}_{2}$ showed significantly negative correlation with DOC $\left(r^{2}=0.54 ; p<0.001\right)$ suggesting that microbial decomposition is the prime factor for inter-annual variations in $\mathrm{pCO}_{2}$ levels in the dam reservoir.

It is also reported [52] that the source of $\mathrm{CO}_{2}$ is of complete allochthonous origin with reference to the $\delta^{13} \mathrm{C}$ values of the DOC recovered in the Rophemel reservoir.

The observed high $\mathrm{pCO}_{2}$ levels in the Godavari estuary during peak discharge period [33] and attributed to modification of organic matter in the dam reservoir. In order to examine this samples were collected in the estuary during dry (April) and peak discharge period (August) (Figure 6). The salinity in the estuary was ranged from $10-31.8$ during dry period of 2010 and 2011. $\mathrm{pH}$ in the dam reservoir was significantly low (6.9 - 7.0) compared
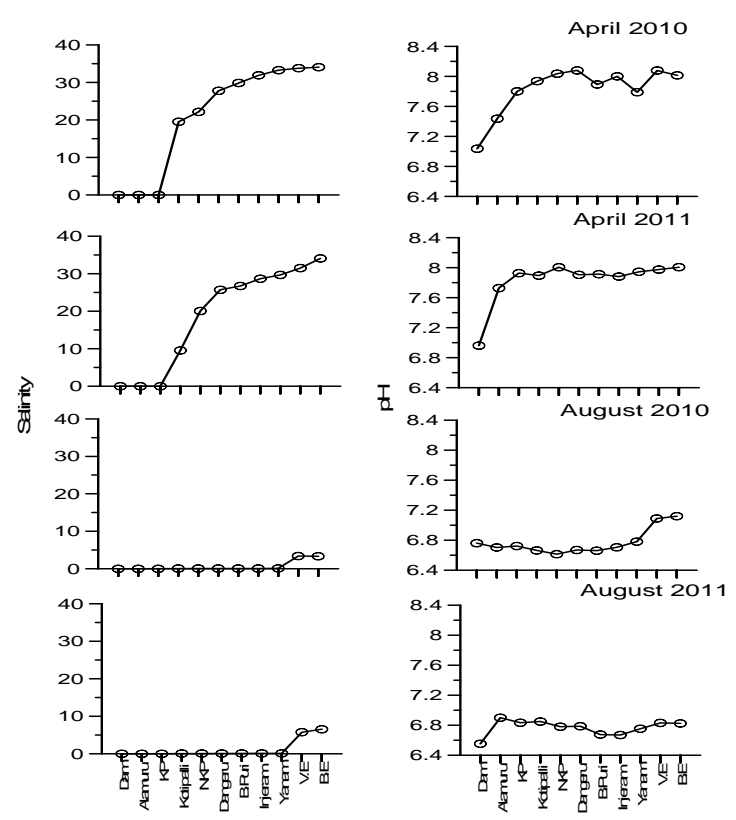

to estuary $(7.4-8.1)$. The DIC concentration ranged from 1577 to $2300 \mu \mathrm{M}$ and slightly higher concentrations were found in the estuary than dam due to high salinity. $\mathrm{pCO}_{2}$ levels in the estuary were significantly low $(<1000 \mu \mathrm{atm})$ than reservoir $(4100-8325 \mu \mathrm{atm})$ as these two water bodies were separated by dam and no interactions occur, within these two water bodies. On the other hand, entire estuary was filled with freshwater during discharge period with small variations in salinity between mouth of the estuary and dam reservoir $(\sim 3.3-6.5)$. $\mathrm{pH}$ during peak discharge period was lower by $\sim 1$ in the entire estuary and DIC decreased up to $1000 \mu \mathrm{M}$ with high $\mathrm{pCO}_{2}$ levels. $\mathrm{pCO}_{2}$ levels in the estuary were almost or slightly higher than dam reservoir due to mixing of sediment pore water during discharge into the estuary. Sharp decrease in $\mathrm{pCO}_{2}$ was noticed close to the mouth of the estuary due to mixing with the seawater. In addition to this, relatively higher $\mathrm{pCO}_{2}$ levels were noticed during August 2010 than 2011 by $\sim 4000 \mu \mathrm{atm}$ and it was consistent with the magnitude of discharge from the dam suggesting that significant modification of inorganic carbon in the dam reservoir made estuary as a strong source of $\mathrm{CO}_{2}$ to the atmosphere.

The wind speed at the reservoir ranged between 0.73 to $3.52 \mathrm{~m} \cdot \mathrm{s}^{-1}$ during study period with high during monsoon (discharge) period. The fluxes of $\mathrm{CO}_{2}$ from the reservoir to the atmosphere ranged between 9.7 and 472.8 mmolC $\mathrm{m}^{-2} \cdot \mathrm{d}^{-1}$ during study period with maximum during peak discharge period and minimum in dry period (Table 2). The mean fluxes during discharge period (251 $\left.\pm 131 \mathrm{mmolC} \mathrm{m}{ }^{-2} \cdot \mathrm{d}^{-1}\right)$ was six time higher than dry period $\left(42 \pm 31 \mathrm{mmolC} \mathrm{m}^{-2} \cdot \mathrm{d}^{-1}\right)$. Such high fluxes during

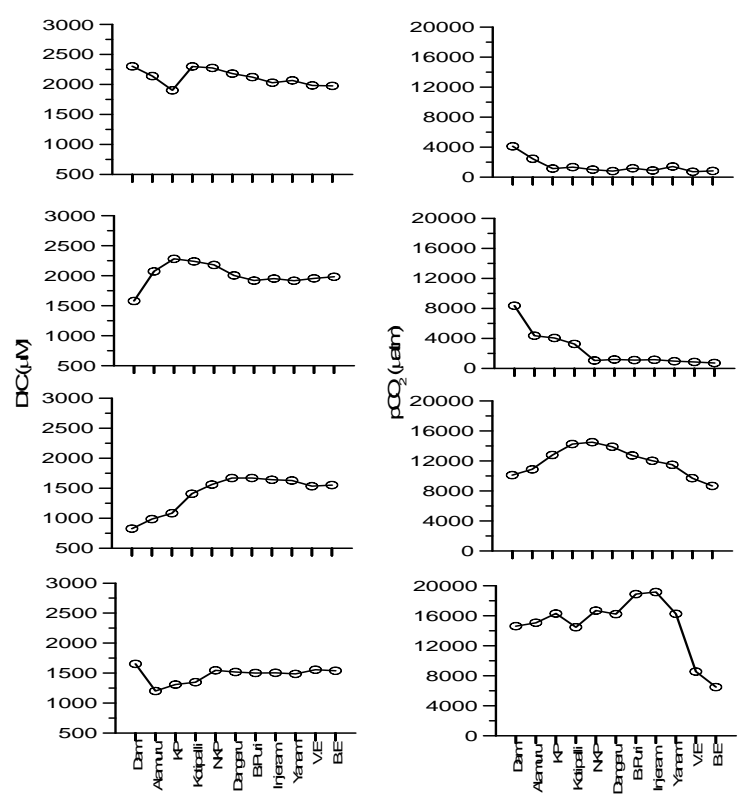

Figure 6. Spatial variations in salinity, $\mathrm{pH}, \mathrm{DIC}$ and $\mathrm{pCO}_{2}$ from Dam reservoir to mouth of the estuary during April and August 2010 and 2011. 
peak discharge period were associated with high winds $\left(3.1 \mathrm{~m} \cdot \mathrm{s}^{-1}\right)$ than dry period $\left(1.2 \mathrm{~m} \cdot \mathrm{s}^{-1}\right)$. The annual mean fluxes of $\mathrm{CO}_{2}$ to the atmosphere amounted to $112 \pm 126$ $\mathrm{mmolC} \mathrm{m}^{-2} \cdot \mathrm{d}^{-1}$ from the Dowleiswaram dam reservoir. The fluxes of $\mathrm{CO}_{2}$ from the Petit Saut reservoir [8], varied from $102-133 \mathrm{mmolC} \mathrm{m}{ }^{-2} \cdot \mathrm{d}^{-1}$ whereas $76 \pm 46$ and $976 \pm 1213 \mathrm{mmolC} \mathrm{m}{ }^{-2} \cdot \mathrm{d}^{-1}$ from the Balbina and Samuel reservoirs [8] respectively. The mean fluxes from the Dowleiswaram dam reservoir was less than the Brazilian reservoirs and higher than French reservoir [8].

In order to compare the $\mathrm{pCO}_{2}$ levels in Dowleiswaram reservoir with elsewhere in the world, $\mathrm{pH}$ and TA data were gathered from the literature and computed for $\mathrm{pCO}_{2}$ using the similar way as mentioned in the materials and method. Various methods were used to estimate TA at different reservoirs, therefore caution must be taken while comparing variations in the reservoirs. $\mathrm{pH}$ in the European reservoirs [24,53,54] were ranged between 6.5 and 9.2 whereas $6.8-8.7$ and 6.0 - 10 were found in the African [20,21] and Asian [15,29,31,35,47,56-59,61] reservoirs. Relatively high $\mathrm{pH}$ was noticed in the European reservoirs compared to other reservoirs with exception of Sariyar reservoir in Turkey where high $\mathrm{pH}$ of 10 was noticed [47]. The $\mathrm{pCO}_{2}$ values were ranged between $1700-13,000 \mu \mathrm{atm}$ in the European reservoirs, 9493 to $10,965 \mu \mathrm{atm}$ in the African [20,21] and 3693 to 11259 $\mu$ atm in the other Indian reservoirs [29,31,58,59] (Table 3). Exceptionally high $\mathrm{pCO}_{2}$ levels were found $(65,785$

Table 3. Temperature, dissolved oxygen, Chlorophyll-a, pH, TA and $\mathrm{pCO}_{2}$ in reservoirs located in the world.

\begin{tabular}{|c|c|c|c|c|c|c|}
\hline Name of the reservoir & Temp $\left({ }^{\circ} \mathrm{C}\right)$ & $\mathrm{DO}(\mu \mathrm{M})$ & Chl-a $\left(\mu \mathrm{g} \cdot \mathrm{l}^{-1}\right)$ & $\mathrm{pH}$ & $\mathrm{TA}\left(\mathrm{mg} \cdot 1^{-1}\right)$ & $\mathrm{pCO}_{2}(\mu \mathrm{atm})$ \\
\hline \multicolumn{7}{|c|}{ American region } \\
\hline Ribeirao das lajes, Brazil [48] & $3-30$ & 256 & - & 7.19 & - & - \\
\hline Balbina, Brazil [8] & $30-31$ & 202 & - & - & - & 19,724 \\
\hline Samuel, Brazil [8] & $31-33$ & 196 & - & - & - & 25,480 \\
\hline Colorado, USA [49] & - & - & $3.8-11.7$ & - & - & - \\
\hline Arizona, USA [50] & & & $0-14$ & & & \\
\hline \multicolumn{7}{|c|}{ European region } \\
\hline Garas, Serbia [17] & $6-28$ & $34-368$ & $3-16.9$ & - & $53-105$ & - \\
\hline Bukulja, Serbia [17] & $11-21$ & $231-425$ & $7-19.2$ & - & $47.5-65$ & - \\
\hline Alton water, UK [22] & - & - & $61-129$ & - & - & - \\
\hline Petit Saut, France [8] & $30-31$ & 202 & - & - & - & $11,500-45,000$ \\
\hline Rophemel, France [52] & - & - & $2-88$ & - & - & - \\
\hline Pena Large, France [53] & $24.6-29.5$ & $203-266$ & $0.5-4.0$ & $6.5-8.5$ & - & - \\
\hline Siemianowka, Poland [60] & - & - & $100-200$ & - & - & - \\
\hline Antoninek, Western Poland [54] & - & $43-443$ & $0.8-41.2$ & $7.4-9.1$ & - & - \\
\hline Dobezyce Czorsztyn Roznow, Poland [24] & - & - & - & $7.2-9.2$ & - & - \\
\hline \multicolumn{7}{|c|}{ African region } \\
\hline Turkwel Gorge, Kenya [20] & $23.6-26.5$ & $175-259$ & $5.6-28.3$ & $7.1-8.7$ & $81.6-108$ & 9493 \\
\hline Oyun, Nigeria [21] & $23.1-29.6$ & $150-256$ & - & $6.8-8.2$ & $30-55$ & 10,965 \\
\hline \multicolumn{7}{|c|}{ Asian region } \\
\hline Sariyar, Turkey [47] & $4-31$ & $187-478$ & 84.5 & $7.4-10$ & - & - \\
\hline Saguling, Indonesia [15] & $23.2-23.9$ & $28-262$ & - & $6.3-8.4$ & - & - \\
\hline Banglang, Thailand [57] & $17-32$ & $10-286$ & $0-12.6$ & $6.0-7.8$ & $15-235$ & 65,785 \\
\hline Hathaikheda, India [31] & - & $37-237$ & - & $7.1-7.6$ & - & - \\
\hline Hirahalla, India [29] & $21.3-27.1$ & $236-263$ & - & $7.5-7.8$ & $30.7-41.6$ & $3693-9857$ \\
\hline Bedua, India [58] & $20.5-30.5$ & $175-259$ & - & $7.5-8.1$ & $68-75.5$ & $4513-11,259$ \\
\hline Khadakwasala, India [59] & $20.1-26.2$ & $226-295$ & - & $6.5-8.6$ & - & - \\
\hline Dowaleiswaram, India [Present Study] & $26.7-33.4$ & $164.1-289.2$ & $1.4-38$ & $6.5-7.5$ & $12.9-32.4$ & $3944-16,042$ \\
\hline
\end{tabular}


$\mu \mathrm{atm})$ in the Banglang, Thailand [57] where acidic $\mathrm{pH}$ (6.0) was found. The $\mathrm{pCO}_{2}$ levels in the Dowleiswaram dam reservoir is in agreement with the reported values from other reservoirs in the world (Table 3). Nevertheless this comparison suggested that dam reservoirs are strong source of $\mathrm{CO}_{2}$ to the atmosphere and their contribution seems to be relatively large in the Asian reservoirs compared to other continental reservoirs. Such high $\mathrm{pCO}_{2}$ levels in the Asian reservoirs could possibly due to high water temperatures, quality and load of organic matter, nutrients, and bacterial abundance.

\section{Summary and Conclusions}

Monthly time-series observations were conducted in the Dowlesiwaram dam reservoir to examine the source of inorganic carbon, and fluxes to the atmosphere. The reservoir receives freshwater during monsoon period when Indian subcontinent received maximum rainfall. The water is stored in the reservoir during dry period when significant modification of carbon system occurs. During the storage period, $\mathrm{pH}$ decreased from 7.5 to 6.4 and oxygen saturation from $\sim 95 \%$ to $65 \%$ suggesting that intense organic matter decomposition leads to occur. Such organic matter decomposition result in the release of nutrients to support autotrophic activity. Occurrence of phytoplankton blooms was noticed during dry and moderate discharge periods. The $\mathrm{pCO}_{2}$ levels were ranging between 3944 and $16,042 \mu \mathrm{atm}$ and higher fluxes were found during the peak discharge period. It was further noticed that $\mathrm{pCO}_{2}$ levels in the estuary, adjacent to the dam reservoir, were $<1000 \mu \mathrm{atm}$ during dry period and were increased to $>15,000 \mu \mathrm{atm}$ during discharge period suggesting that high fluxes of $\mathrm{CO}_{2}$ reported from the estuary were contributed by the discharge of acidic waters from the dam reservoir. Our study also indicates that the Dowleiswarm dam reservoir is a strong source of $\mathrm{CO}_{2}$ to atmosphere even though it is much smaller than Brazilian (tropical) reservoir. India houses 376 major and medium reservoirs and contribution from all these reservoirs requires further studies in the future.

\section{Acknowledgements}

The authors are grateful to Director, NIO, Goa and Scientist-in-charge, NIO, Regional Centre, Visakhapatnam for constant encouragement. Two of us (M H K P \& V V S) are thankful to CSIR for the award of SRF and Emeritus Scientist respectively. This is NIO contribution number 5334 .

\section{REFERENCES}

[1] J. A. Downing, J. J. Cole, J. J. Middelburg, R. G. Striegl, C. M. Duarte, P. Kortelainen, Y. T. Prairie and K. A. Laube, "Sediment Organic Carbon Burial in Agricultur- ally Eutrophic Impoundments over the Last Century,' Global Biogeochemical Cycles, Vol. 22, No. 1, 2008, pp. 1-10. doi:10.1029/2006GB002854

[2] L. J. Tranvik, J. A. Downing, J. B. Cotner, S. A. Loiselle, R. G. Striegl, T. J. Ballatore, P. Dillon, K. Finlay, K. Fortino and L.B. Knoll, "Lakes and Reservoirs as Regulators of Carbon Cycling and Climate," Limnology and Oceanography, Vol. 54, No. 6, 2009, pp. 2298-2314. doi:10.4319/10.2009.54.6 part_2.2298

[3] J. W. M. Rudd, R. Harris, C. A. Kelly and R. E. Hecky, "Are Hydroelectric Reservoirs Significant Sources of Greenhouse Gases?" AMBIO: A Journal of the Human Environment, Vol. 22, No. 4, 1993, pp. 246-248.

[4] C. A. Kelly, J. Rudd, R. Bodaly, N. Roulet, V. L. S. Louis, A. Heyes, T. Moore, S. Schiff, R. Aravena and K. Scott, "Increases in Fluxes of Greenhouse Gases and methyl Mercury Following Flooding of an Experimental Reservoir," Environmental Science \& Technology, Vol. 31, No. 5, 1997, pp. 1334-1344. doi:10.1021/es9604931

[5] G. Abril, F. Guérin, S. Richard, R. Delmas, C. Galy-Lacaux, P.Gosse, A. Tremblay, L. Varfalvy, M. A. Dos Santos and B. Matvienko, "Carbon Dioxide and Methane Emissions and the Carbon Budget of a 10-Year Old Tropical Reservoir (Petit Saut, French Guiana)," Global Biogeochemical Cycles, Vol. 19, No. 4, 2005, p. 16. doi:10.1029/2005GB002457

[6] F. Roland, L. O. Vidal, F. S. Pacheco, N. O. Barros, A. Assireu, J. P. H. B. Ometto, A. C. P. Cimbleris and J. J. Cole, "Variability of Carbon Dioxide Flux from Tropical (Cerrado) Hydroelectric Reservoirs," Aquatic Sciences Research Across Boundaries, Vol. 72, No. 3, 2010, pp. 283-293. doi:10.1007/s00027-010-0140-0

[7] J. J. Cole, N. F. Caraco, G. W. Kling and T. K. Kratz, "Carbon Dioxide Supersaturation in the Surface Waters of Lakes," Science, Vol. 265, No. 5178, 1994, pp. 15681568. doi: $10.1126 /$ science. 265.5178 .1568

[8] F. Guerin, G. Abril, S. Richard, B. Burban, C. Reynouard, P. Seyler and R. Delmas, "Methane and Carbon Dioxide Emissions from Tropical Reservoirs: Significance of Downstream Rivers," Geophysical Research Letters, Vol. 33, No. 21, 2006, p. 6. doi:10.1029/2006GL027929

[9] W. Graneli, M. Lindell and L. Tranvik, "Photo-Oxidative Production of Dissolved Inorganic Carbon in Lakes of Different Humic Content," Limnology and Oceanography, Vol. 41, No. 4, 1996, pp. 698-706.

doi:10.4319/10.1996.41.4.0698

[10] E. G. Stets, R. G. Striegl, G. R. Aiken, D. O. Rosenberry and T. C. Winter, "Hydrologic Support of Carbon Dioxide Flux Revealed by Whole-Lake Carbon Budgets," Journal of Geophysical Research, Vol. 114, No. G1, 2009, p. 14. doi:10.1029/2008JG000783

[11] J. J. Cole, Y. T. Prairie, N. F. Caraco, W. H. McDowell, L. J. Tranvik, R. G. Striegl, C. M. Duarte, P. Kortelainen, J. A. Downing, J. J. Middelburg and J. Melack, "Plumbing the Global Carbon Cycle: Integrating Inland Waters into the Terrestrial Carbon Budget," Ecosystems, Vol. 10, No. 1, 2007, pp. 171-184. doi:10.1007/s10021-006-9013-8

[12] C. M. Duarte and Y. T. Prairie, "Prevalence of Hetero- 
trophy and Atmospheric $\mathrm{CO}_{2}$ Emissions from Aquatic Ecosystems," Ecosystems, Vol. 8, No. 7, 2005, pp. 862870. doi:10.1007/s10021-005-0177-4

[13] P. A. Del Giorgio, J. J. Cole and A. Cimbleris, "Respiration Rates in Bacteria Exceed Phytoplankton Production in Unproductive Aquatic Systems," Nature, Vol. 385, No. 6612, 1997, pp. 148-151. doi:10.1038/385148a0

[14] S. Sobek, L. J. Tranvik and J. J. Cole, “Temperature InDependence of Carbon Dioxide Supersaturation in Global Lakes," Global Biogeochemical Cycles, Vol. 19, No. 2, 2005, p. 10. doi:10.1029/2004GB002264

[15] B. T. Hart, W. Van Dok and N. Djuangsih, "Nutrient Budget for Saguling Reservoir, West Java, Indonesia," Water Research, Vol. 36, No. 8, 2002, pp. 2152-2160. doi:10.1016/S0043-1354(01)00428-6

[16] F. J. Rueda, W. E. Fleenor and I. de Vicente, "Pathways of River Nutrients towards the Euphotic Zone in a DeepReservoir of Small Size: Uncertainty Analysis," Ecological Modeling, Vol. 202, No. 3, 2007, pp. 345-361.

[17] V. Karadžić, G. Subakov-Simić, J. Krizmanić, D. Natić, "Phytoplankton and Eutrophication Development in the Water Supply Reservoirs Garaši and Bukulja (Serbia)," Desalination, Vol. 255, No. 1, 2010, pp. 91-96. doi:10.1016/j.desal.2010.01.009

[18] M. C. A. Calijuri, "Estrutura Fitoplanctônica em um Reservatório Tropical (Barra Bonita, SP)," Tese (Doutorado de Livre-Docência), Universidade de São Paulo, São Carlos, 1999.

[19] E. C. Rivera, J. Ferraz de Queiroz, J. M. Ferraz and E. Ortega, "Systems Models to Evaluate Eutrophication in the Broa Reservoir, São Carlos, Brazil," Ecological Modeling, Vol. 202, No. 3-4, 2007, pp. 518-526.

[20] K. Kotut, S. G. Njuguna, F. M. Muthuri and L. Krienitz, "The Physico-Chemical Conditions of Turkwel Gorge Reservoir, a New Man Made Lake in Northern Kenya," Limnologica-Ecology and Management of Inland Waters, Vol. 29, No. 4, 1999, pp. 377-392. doi:10.1016/S0075-9511(99)80046-2

[21] M. K. Mustapha, "Assessment of the Water Quality of Oyun Reservoir, Offa, Nigeria, Using Selected PhysicoChemical Parameters," Turkish Journal of Fisheries and Aquatic Sciences, Vol. 8, 2008, pp. 309-319.

[22] R. G. Perkins and R. J. C. Underwood, "Gradients of Chlorophyll $a$ and Water Chemistry along an Eutrophic Reservoir with Determination of the Limiting Nutrient by in Situ Nutrient Addition," Water Research, Vol. 34, No. 3, 2000, pp. 713-724. doi:10.1016/S0043-1354(99)00228-6

[23] Y. Jiang and Z. Ma, "An Evaluation of Water Quality from Locations of Huangyang Reservoir," Procedia Environmental Sciences, Vol. 12, 2012, pp. 280-284. doi:10.1016/j.proenv.2012.01.278

[24] E. Szarek-Gwiazda and G. Mazurkiewicz-Boroń, “A Comparison between the Water Quality of the Main Tributaries to Three Submontane Dam Reservoirs and the Sediment Quality in Those Reservoirs," Oceanological and Hydrobiological Studies, Vol. 39, No. 3, 2010, pp. 55-63.

[25] D. Uhlmann, M. Hupfer and C. Appelt, "Discrepancies between Sediment Composition and Tropic Character of Reservoirs," Verhandlungen des Internationalen Verein Limnologie, Vol. 25, 1994, pp. 181-182.

[26] W. Scharf, "Restoration of the Highly Eutrophic Lingese Reservoir," Hydrobiologia, Vol. 416, 1999, pp. 85-96. doi:10.1023/A:1003851102095

[27] G. Mazurkiewicz-Boroń, "Factors of Eutrophication Processes in Sub-Mountain Dam Reservoirs," Supplementa ad Acta Hydrobiologica, Vol. 2, 2002, pp. 1-68.

[28] U. Jayabhaye, "Studies on Physico-Chemical Parameters of Parola Dam in Hingoli District-Maharashtra," Shodh, Samiksha aur Mulyankan International Research Journal, Vol. 2, 2009, pp. 44-46.

[29] R. M. Mullar, M. Rajashekhar, K. Vijaykumar and N. S. Haliked, "Seasonal Variation in Physico-Chemical Parameters of Hirahalla reservoir, Koppal District, Karnataka," International Journal of Systems Biology, Vol. 2, No. 2, 2010, pp. 16-20.

[30] A. K. Agarwal and G. S. Rajwar, "Physico-Chemical and Microbiological Study of Tehri Dam Reservoir, Garhwal Himalaya, India," Journal of American Science, Vol. 6, No. 6, 2010, pp. 65-71.

[31] G. R. Namdev, A. Bajpai and S. Malik, "Assessment of Chemical Fertilizers on the Quality of Water at Hathaikheda Reservoir in Bhopal (M.P.)," International Journal of Pharma and Bio Sciences, Vol. 2, No. 3, 2011, pp. 264-268.

[32] V. V. S. S. Sarma, V. R. Prasad, B. S. K. Kumar, K. Rajeev, B. M. M. Devi, N. P. C. Reddy, V. V. Sarma and M. D. Kumar, "Intra-Annual Variability in Nutrients in the Godavari Estuary, India," Continental Shelf Research, Vol. 30, No. 19, 2010, pp. 2005-2014.

doi:10.1016/j.csr.2010.10.001

[33] V. V. S. S. Sarma, N. A. Kumar, V. R. Prasad, V. Venkataramana, S. Appalanaidu, B. Sridevi, B. S. K. Kumar, M. D. Bharati, C. V. Subbaiah, T. Acharyya, G. D. Rao, R. Viswanadham, L. Gawade, D. T. Manjary, P. P. Kumar, K. Rajeev, N. P. C. Reddy, V. V. Sarma, M. D. Kumar, Y. Sadhuram and T. V. R. Murty, "High $\mathrm{CO}_{2}$ Emissions from the Tropical Godavari Estuary (India) Associated with Monsoon River Discharges," Geophysical Research Letters, Vol. 38, No. 8, 2011, p. 4. doi:10.1029/2011GL046928

[34] V. V. S. S. Sarma, S. N. M. Gupta, P. V. R. Babu, T. Acharya, N. Harikrishnachari, K. Vishnuvardhan, N. S. Rao, N. P. C. Reddy, V. V. Sarma, Y. Sadhuram, T. V. R. Murty and M. D. Kumar, "Influence of River Discharge on Plankton Metabolic Rates in the Tropical Monsoon Driven Godavari Estuary, India," Estuarine, Coastal and Shelf Science, Vol. 85, No. 4, 2009, pp. 515-524. doi:10.1016/j.ecss.2009.09.003

[35] V. V. S. S. Sarma, R. Viswanadham, G. D. Rao, V. R. Prasad, B. S. K. Kumar, S. A. Naidu, N. A. Kumar, D. B. Rao, T. Sridevi, M. S. Krishna, N. P. C. Reddy, Y. Sadhuram and T. V. R. Murty, "Carbon Dioxide Emissions from Indian Monsoonal Estuaries," Geophysical Research Letters, Vol. 39, No. 3, 2012, pp. 1-5. doi:10.1029/2011GL050709

[36] T. Acharyya, V. V. S. S. Sarma, B. Sridevi, V. Venkata- 
ramana, M. D. Bharathi, S. A. Naidu, B. S. K. Kumar, V. R. Prasad, D. Bandyopadhyay, N. P. C. Reddy and M. D. Kumar, "Reduced River Discharge Intensifies Phytoplankton Bloom in Godavari Estuary, India," Marine Chemistry, Vol. 132-133, 2012, pp. 15-22. doi:10.1016/j.marchem.2012.01.005

[37] D. E. Carritt and J. H. Carpenter, "Comparison and Evaluation of Currently Employed Modifications of the Winkler Method for Determining Dissolved Oxygen in Seawater; a NASCO Report," Journal of Marine Research, Vol. 24, 1966, pp. 286-318.

[38] K. Grasshoff, M. Ehrhardt, K. Kremling and T. Almgren, "Methods of Seawater Analysis," Wiley Online Library, 1983.

[39] R. Suzuki and T. Ishimaru, "An Improved Method for the Determination of Phytoplankton Chlorophyll Using N, N-Dimethylformamide," Journal of Oceanography, Vol. 46, No. 4, 1990, pp. 190-194.

[40] A. G. Dickson and C. Goyet, "Hand Book of Methods for the Analysis of the Various Parameters of the Carbon Dioxide System in Seawater," Version 2, DOE, 1994.

[41] F. J. Millero, T. B. Graham, F. Huang, H. Bustos-Serrano and D. Pierrot, "Dissociation Constants of Carbonic Acid in Seawater as a Function of Salinity and Temperature," Marine Chemistry, Vol. 100, No. 1-2, 2006, pp. 80-94. doi:10.1016/j.marchem.2005.12.001

[42] P. R. P. Medeiros, B. A. Knoppers, G. H. Cavalcante and W. F. Landim de Souza, "Changes in Nutrient Loads (N, $\mathrm{P}$ and $\mathrm{Si}$ ) in the Sao Francisco Estuary after the Construction of Dams," Brazilian Archives of Biology and Technology, Vol. 54, No. 2, 2011, pp. 387-397.

[43] S. R. Carpenter, J. J. Cole, J. F. Kitchell and M. L. Pace, "Impact of Dissolved Organic Carbon, Phosphorus, and Grazing on Phytoplankton Biomass and Production in Experimental Lakes," Association for the Sciences of Limnology and Oceanography, Vol. 43, No. 1, 1998, pp. 73-80. doi:10.4319/10.1998.43.1.0073

[44] R. Carignan, D. Planas and C. Vis, "Planktonic Production and Respiration in Oligotropic Shield Lakes," Association for the Sciences of Limnology and Oceanography, Vol. 45, No. 1, 2000, pp. 189-199. doi:10.4319/10.2000.45.1.0189

[45] A. Bode and E. Fernandez, "Influence of Water-Column Stability on Phytoplankton Size and Biomass Succession Patterns in the Central Cantabrian Sea (Bay of Biscay)," Journal of Plankton Research, Vol. 14, No. 6, 1992, pp. 885-902. doi:10.1093/plankt/14.6.885

[46] R. Rengarajan and V. V. S. S. Sarma, "Submarine Groundwater Discharge and Nutrients Addition to the Coastal Zone of the Godavari Estuary," Marine Chemistry, 2012, in press.

[47] T. Atici and O. Obali, "Seasonal Variation of Phytoplankton and Value of Chlorophylla in the Sariyar Dam Reservoir (Ankara, Turkey)," Turkish Journal of Botany, Vol. 30, 2006, pp. 349-357.

[48] A. W. S. Guarino, C. W. C. Branco, G. P. Dinizi and R. Rocha, "Limnological Characteristis of an Old Tropical Reservoir (Ribeirao das Lajes Reservoir, RJ, Brazil)," Acta Limnologica Brasiliensia, Vol. 17, No. 2, 2005, pp.
129-141.

[49] R. F. Arenz Jr., W. M. Lewis Jr. and J. F. Saunders, "Determination of Chlorophyll and Dissolved Organic Carbon from Reflectance Data for Colorado Reservoirs," International Journal of Remote Sensing, Vol. 17, No. 8, 1996, pp. 1547-1566. doi:10.1080/01431169608948723

[50] H. Mash, P. K. Westerhoff, L. A. Baker, R. A. Nieman and M. L. Nguyen, "Dissolved Organic Matter in Arizona Reservoirs: Assessment of Carbonaceous Sources," Organic Geochemistry, Vol. 35, No. 7, 2004, pp. 831-843. doi:10.1016/j.orggeochem.2004.03.002

[51] G. Abril, S. Richard and F. Guérin, "In Situ Measurements of Dissolved Gases $\mathrm{CO}_{2}$ and $\mathrm{CH}_{4}$ in a Wide Range of Concentrations in a Tropical Reservoir Using an Equilibrator," Science of the Total Environment, Vol. 354, No. 2-3, 2006, pp. 246-251. doi:10.1016/j.scitotenv.2004.12.051

[52] A. C. Pierson-Wickmann, G. Gruau, E. Jardé, N. Gaury, L. Brient, M. Lengronne, A. Crocq, D. Helle and T. Lambert, "Development of a Combined Isotopic and Mass-Balance Approach to Determine Dissolved Organic Carbon Sources in Eutrophic Reservoirs," Chemosphere, Vol. 83, No. 3, 2011, pp. 356-366. doi:10.1016/j.chemosphere.2010.12.014

[53] B. Bellanger, S. Huona, P. Steinmann, F. Chabaux, F. Velasquez, V. Valles, K. Arn, N. Clauer and A. Mariotti, "Oxic-Anoxic Conditions in the Water Column of a Tropical Freshwater Reservoir (Peña-Large dam, NW Venezuela)," Applied Geochemistry, Vol. 19, No. 8, 2004, pp.1295-1314. doi:10.1016/j.apgeochem.2003.11.007

[54] R. Dondajewska, "Effect of Restoration of a Lowland Dam Reservoir on River Water Quality," Limnological Review, Vol. 7, No. 4, 2003, pp. 185-190.

[55] J. Y. Lee, Y. K. Choi, H. S. Kim and S. T. Yun, "Hydrologic Characteristics of a Large Rockfill Dam: Implications for Water Leakage," Engineering Geology, Vol. 80, No. 1-2, 2005, pp. 43-59.

doi:10.1016/j.enggeo.2005.03.002

[56] S. Wang, R. M. Dong, C. Z. Dong, L. Huang, H. Jiang and H. Dong, "Diversity of Microbial Plankton across the Three Gorges Dam of the Yangtze River, China," Geoscience Frontiers, Vol. 3, No. 3, 2012, pp. 335-349. doi:10.1016/j.gsf.2011.11.013

[57] C. Ariyadej, T. Pimpan and T. Reungchai, "Varition of Phytoplankton Biomass as Chlorophyll $a$ in Banglang Reservoir, Yala Province," Songklanakarin Journal of Science and Technology, Vol. 30, No. 2, 2008, pp. 159166.

[58] P. K. Verma and J. D. Munshi, "Limnology of Badua Reservoir of Bhagalpur, Bihar," Proceedings of the Indian National Science Academy, Vol. 6, 1983, pp. 598609.

[59] P. N. Kamble, S. J. Kokate, H. R. Aher and S. R. Kuchekar, "Seasonal Variation in Physico-Chemical Parameters of Khadakwasala Reservoir," Rasayan Journal of Chemistry, Vol. 1, No. 1, 2008, pp. 63-67.

[60] E. Jekatierynczuk-Rudczyk, A. Gorniak, P. Zielinski, J. Dziemian, "Daily Dynamics of Water Chemistry in a Lowland Polyhumic Dam Reservoir," Polish Journal of 
Environmental Studies, Vol. 11, No. 5, 2002, pp. 521526.

[61] H. Zeng, L. Song, Z. Yu and H. Chen, "Distribution of Phytoplankton in the Three-Gorge Reservoir during
Rainy and Dry Seasons," Science of the Total Environment, Vol. 367, No. 2-3, 2006, pp. 999-1009. doi:10.1016/j.scitotenv.2006.03.001 